\title{
FACTORS AFFECTING THE TUITION FEE POLICY OF PUBLIC HIGHER EDUCATION
}

\author{
Nguyen Thi Hoai Trinh \\ Bucharest University of Economic Studies \\ hoaitrinh.hce@gmail.com
}

\begin{abstract}
The purpose of this study is to clarify the factors affecting the student's expected tuition fees in the context that most public universities in Vietnam are not financially self-sufficient, given the relatively limited state budget. That is why public universities are interested in the expected tuition fees of students so that they can change their policies accordingly in allocating available resources. Enhance its competitive position with universities with similar tuition fees. This competition contributes to improving the quality of the whole higher education system. The study identifies the factors affecting the tuition policies in public higher education through the quantitative research method by analyzing questionnaires collected from 250 students from 6 public universities in Vietnam. The results show that the factors affecting tuition fees of public higher education in Vietnam are: (1) Lecturers (L), (2) Curriculums (Cr), (3) Student skills (Ss), (4) Teaching methods (Tm), (5) Facilities (F), (6) Curriculums content (Cc), (7) Course structure (Cs). Based on research results, the study also proposes solutions to improve tuition policies to support learners at public universities in Vietnam.
\end{abstract}

Keywords: Higher education, public universities, tuition fee, factors.

\section{INTRODUCTION}

Higher education is the highest level of education in the national education system. It plays an essential role in building and developing human resources as well as training and providing the future's primary workforce. At the same time, it is the premise for economic growth and development in all aspects of social life. To develop higher education is to develop the quality of human resources, which in turn increases the social labor productivity, and increases income for the trained workers themselves. Therefore, higher education is also considered a market with unique goods and services, and tuition fees are thus "prices" that impact the school's benefits. This market is the primary reason that the states, businesses, training institutions, families, and students are increasingly willing to invest more in higher education.

Although Vietnam's economic conditions are still challenging in recent years, the Government is still paying attention to and has spent a significant proportion of the state budget on investing in public higher education. However, despite the great need to increase training size and quality, the state budget for investment in education, especially public higher education, is still relatively modest. Besides, the state budget investment is only average and not fulfilling the training needs, job structure, and end results of operations of public 
higher education institutions. Most of the tuition fees are applied in accordance with the State's current regulations and are maintained at such a low level that it could not offset the regular costs. In order to solve this problem, higher education cost-sharing is considered the suitable solution for Vietnam. Many countries have implemented cost-sharing policies with their governments through student and household contributions (Teixeira \& Dill, 2011). In another study (Brian, 2010), some countries such as Australia, Canada, Italy, Japan, Netherlands, New Zealand, Spain, and the United States are implementing the student tuition system to share the budget for higher education with the government, creating a variety of student support programs such as the student education loan program in Australia. Even China, which is not a capitalistic country and is influenced by Confucian education, has moved towards a more commercial approach to the expansion of higher education business (Dongping, 2006); and it can be asserted that a 'top-up' fee policy is an essential and straightforward way to achieve the 'New Labor' vision of a 'knowledge economy' (Brian, 2010). Market reforms reflect a change in the state's role with deregulation, increased private funding, and private provision (Jungblut \& Vukasovic, 2017).

However, to determine an appropriate tuition fee, which can ensure, firstly, sufficient funding for the school to maintain and improve higher education quality, and secondly, equity and access to higher education for the people, analysis of tuition policies from the learners' perspective is very important; thirdly, the benefit of enhancing the independence of universities by making them less dependent on government funding (Department for Education and Skills, 2003). Exploring the economic factors that affect students' choices is one of the most researched topics in higher education finance (Heller, 1997).

Studying the factors affecting the tuition fees of public higher education is of high practical relevance. These factors contribute to improving the competitiveness of universities and empowering public higher education institutions. This study aims at the following primary objectives: (1) Analysis of factors affecting tuition policies for public higher education and the degree of influence of these factors on tuition policies for public higher education in Vietnam. (2) Proposal of some solutions to improve tuition policies to support students at public universities in Vietnam.

\section{LITERATURE REVIEW}

In the era of the knowledge economy, the competition between universities is increasing. Student satisfaction has become an important topic in educational research. Some authors (Arambewela \& J, 2006) emphasize that student satisfaction is the primary basis for competitive leadership and has become a significant target for universities. Student satisfaction is a vital source of evidence for universities, but student dissatisfaction can create a public complaint environment to a higher education institution's negative image 
(Fitzpatrick et al., 2012). Therefore, the service quality of the university has a direct impact on student expectations.

Several authors (Farahmandian et al., 2013) examined the effect of perceived service quality on student satisfaction in higher education in International Business School, University of Technology, Malaysia by taking a random sample and collecting responses from 225 students. The study results show that five factors investigated, namely facilities, consulting, services, curriculum, financial aid, and tuition, have a positive impact on students' expectations. In another study, (Thomas \& Galambos, 2004) focused on the faculty and the role of departments in shaping student satisfaction.

According to Chua (2004) and Merican et al. (2009), training quality is a multi-directional and subjective concept, because in each different customer group, there will be different views on the quality of training, and in each group, there will also be different personal and social views. Therefore, in order to satisfy their target customers well, training organizations must know the quality attributes of each target customer group. According to Chua's study (2004), there are four perspectives on higher education quality: the parent's perspective, the faculty member' perspective, the recruiter's perspective, and the learner's perspective. The study results also show that quality focuses mainly on the process and output (process $46.6 \%$, output $46.6 \%$, and input 6.8\%).

If higher education is considered as a unique good and service market according to the law of supply and demand, tuition fees are "prices," which impact the school's revenue (Leslie \& Brinkman, 1987). Tuition fees affect a student's decision to choose a university (Leslie \& Brinkman, 1987). Tuition fees affect a student's decision to choose a university (Chapman, 1981).

College tuition is the households'/students' payment for college education benefits, such as better employment opportunities in the future and a higher lifetime income (Kobe University \& UNESCO Bangkok, 2014). College tuition is the price that students and parents pay for higher education services for personal gain (Huang \& Wu, 2008).

Another interesting study (Chapman, 1981) proposed a general model of students' choice of university through two factor groups that significantly influence students' decision to choose a university. These are individual and family characteristics, and external factors such as individuals, permanent university characteristics, and the university's efforts to communicate with students. The study results have been used and developed by other groups to study the factors that influence a student's choice of college. Also, through the payment of tuition fees for public universities, students realize their interests. The higher the fees students pay, the greater the benefits they expect from the university (Callender, 2006). Therefore, allowing schools to collect fees is to create a customer-producer relationship in higher education, promoting higher education quality (Hung, 2016). 
Service quality and satisfaction are two different but closely related concepts in a study about service (Parasuraman et al., 1988).

Therefore, to improve a university's position, it is required that the university have appropriate policies corresponding to wishes of students. Tuition is one of the students' first concerns.

\section{RESEARCH METHODOLOGY}

\subsection{Research model and research hypothesis}

\section{a. Research model}

The general research model in the study is determined as follows:

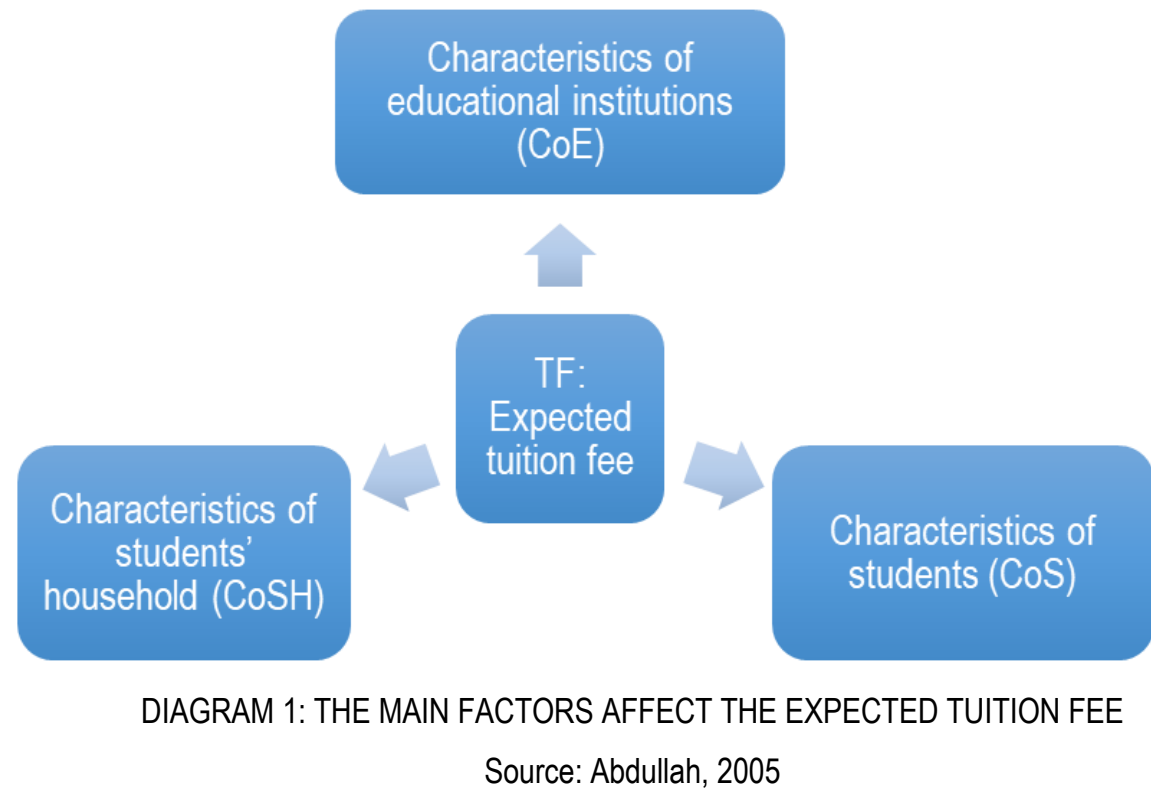

TF: Expected tuition fee

Characteristics of educational institutions ( $\mathrm{COE})$ : The group of factors represents the characteristics of the public higher education institution.

Characteristics of students (CoS): The group of factors represents the student's characteristics.

Characteristics of students' household (CoSH): The group of factors represents the student's household characteristics.

\section{b. Research hypothesis}

\section{TABLE 1. THE RESEARCH HYPOTHESIS}

\begin{tabular}{|c|c|c|c|}
\hline Factors & Signs & Variable name & Origin of the scale \\
\hline $\begin{array}{c}\text { Characteristics } \\
\text { of educational } \\
\text { institutions (CoE) }\end{array}$ & CS & $\begin{array}{c}\text { The course structure has a positive } \\
\text { impact on the expected tuition fees } \\
\text { of students. }\end{array}$ & Authors' proposition \\
\hline
\end{tabular}


Nguyen, $\mathrm{T}$.

FACTORS AFFECTING THE TUITION FEE POLICY OF PUBLIC HIGHER EDUCATION

\begin{tabular}{|c|c|c|c|}
\hline & $L$ & $\begin{array}{l}\text { Lecturers have a positive impact on } \\
\text { the expected tuition fees of } \\
\text { students. }\end{array}$ & $\begin{array}{l}\text { Authors' proposition based on the } \\
\text { theory of some authors (Thomas } \\
\text { \& Galambos, 2004) \& (Abdullah, } \\
\text { 2005) }\end{array}$ \\
\hline & $\mathrm{CC}$ & $\begin{array}{c}\text { Curriculum contents have a positive } \\
\text { impact on the expected tuition fees } \\
\text { of students. }\end{array}$ & $\begin{array}{l}\text { Authors' proposition based on the } \\
\text { theory of some authors (Biggs, } \\
\text { 1993) \& (Abdullah, 2005) } \\
\text { (Merican et al., 2009) }\end{array}$ \\
\hline & TM & $\begin{array}{c}\text { Teaching methods have a positive } \\
\text { impact on the expected tuition fees } \\
\text { of students. }\end{array}$ & $\begin{array}{l}\text { Authors' proposition based on the } \\
\text { theory of some authors (Biggs, } \\
\text { 1993) (Merican et al., 2009) }\end{array}$ \\
\hline & $F$ & $\begin{array}{c}\text { Facilities have a positive impact on } \\
\text { the expected tuition fees of } \\
\text { students. }\end{array}$ & $\begin{array}{c}\text { Applicable with scale adjustment } \\
\text { of some authors (Hung, 2016) \& } \\
\text { (Abdullah, 2005) }\end{array}$ \\
\hline & $\mathrm{CR}$ & $\begin{array}{l}\text { Curriculums have a positive impact } \\
\text { on the expected tuition fees of } \\
\text { students. }\end{array}$ & $\begin{array}{l}\text { Authors' proposition based on the } \\
\text { study of some authors }\end{array}$ \\
\hline \multirow{2}{*}{$\begin{array}{l}\text { Characteristics } \\
\text { of students } \\
\text { (CoS): The } \\
\text { group of factors } \\
\text { represents the } \\
\text { student's } \\
\text { characteristics }\end{array}$} & G & $\begin{array}{l}\text { The difference in the expected } \\
\text { tuition fee of students by gender }\end{array}$ & Authors' proposition \\
\hline & $\mathrm{TI}$ & $\begin{array}{l}\text { The difference in the expected } \\
\text { tuition fee of students by training } \\
\text { institution }\end{array}$ & $\begin{array}{c}\text { Applicable with scale adjustment } \\
\text { of some authors (Hung, 2016) \& } \\
\text { (Abdullah, 2005) }\end{array}$ \\
\hline \multirow{2}{*}{$\begin{array}{l}\text { Characteristics } \\
\text { of students' } \\
\text { household } \\
\text { (CoSH): The } \\
\text { group of factors } \\
\text { represents the } \\
\text { students' } \\
\text { household } \\
\text { characteristics }\end{array}$} & $\mathrm{R}$ & $\begin{array}{c}\text { The difference in the expected } \\
\text { tuition fee of students by residence } \\
\text { of students }\end{array}$ & $\begin{array}{c}\text { Applicable with scale adjustment } \\
\text { of some authors (Hung, 2016) \& } \\
\text { (Abdullah, 2005), (Merican et al., } \\
\text { 2009) }\end{array}$ \\
\hline & TGI & $\begin{array}{l}\text { The difference in the expected } \\
\text { tuition fee of students by total } \\
\text { guardian income }\end{array}$ & Authors' proposition \\
\hline
\end{tabular}

Source: the authors synthesize and propose

\subsection{Survey sample and data collection}

\section{a. Subject and scope of the survey}

The subjects of the article are students from 6 public universities: Danang University of Science and Education, Hue University of Medicine and Pharmacy, Danang University of Economics, Hue University of Laws, The University of Social Sciences and Humanities Vietnam National University Ho Chi Minh City, and Hanoi National University of Civil Engineering. The survey was conducted online through the questionnaire. The survey method performed is the convenient sampling method. 


\section{b. Survey timeline and progress}

The survey was conducted in the form of face-to-face interviews using a simple random sampling method. The survey period is 30 days, from December 15, 2020 to January 15, 2021. After January 15, 2021, the author received 250 responses with complete information as asked by the questionnaire.

\section{c. The scale}

\section{For the factor $\mathrm{CoE}$}

One of the most commonly used forms of measuring abstract concepts in socio-economic research is the scale introduced by Rensis Likert (Likert, 1932). Likert presented the scales with levels 3,5, 7, .. depending on the sample size. The scale for the CoE variable is built in the thesis based on 5 levels, as follows:

1- $\quad$ Strongly disagree; 2 - Disagree; 3 - Neutral; 4 - Agree; 5 - Strongly agree.

\section{For the factor CoS}

The gender $(G)$ variable will take 1 of 2 values: 0 . Male, 1 . Female

The training institution (TI) variable will receive 1 of 6 values: 1. Pedagogy; 2. Medicine; 3. Economics; 4. Law; 5 . Science and Humanities; 6 . Construction

\section{For the factor $\mathrm{CoSH}$}

The residence $(R)$ variable will take 1 of 4 values: 1. Mountainous ethnic group (Area 1), 2. Town or City (Area 2), 3. Vicinity (Area 2 rural), 4. Urban districts (Area 3).

The total guardian income (TGI) variable will take one of the five values: 1. Under 500 USD 2. 500-1000 USD 3. 1000-1500 USD 4. 1500-2000 USD 5. Over 2000 USD

\section{Methods of data synthesis, processing, and analysis}

The study uses IBM SPSS Statistics 22 statistical analysis software to apply exploratory factor analysis to identify the factors that mainly affect learners' expected tuition fees. The exploratory factor analysis results serve as the basis for proposing several solutions to improve tuition policy in line with higher education institutions' expectations.

Step 1: The author uses descriptive statistics to present characteristics of educational institutions, students, and households.

Step 2: Evaluate the quality of the scale with Cronbach's Alpha coefficients

To preliminarily assess the scale, we evaluate the reliability of the scale with Cronbach's alpha coefficients. According to Hafiz \& Shaari (2013), the variables with corrected item-total correlation less than 0.3 will be disqualified, only chose when it has Cronbach's Alpha reliability of 0.6 or more (Nunnally \& Bernstein, 1994). Many researchers think that Cronbach's alpha from 0.8 to almost 1 scale are good; 0.7 to 0.8 are usable, and 0.6 or more are usable in cases where the concept under study is new or new 
to the study's respondent. Therefore, for this study, the variables have corrected item-total correlation coefficients of less than 0.3 , and the scale component with Cronbach's Alpha coefficient less than 0.6 is considered for removal.

Step 3: Exploratory factor analysis

Exploratory factor analysis (EFA) is used to determine convergent values, discriminant values, and narrow estimated parameters for groups of variables. The Bartlett test is used to consider whether a correlation matrix is a unit matrix or not. Bartlett test is statistically significant when Sig. $<0.05$; proving that the observed variables are correlated with each other in the population. This method is only used when the coefficient KMO (Kaiser-Meyer-Olkin) is 0.5 or more. If $\mathrm{KMO}<0.5$, a factor analysis is not suitable for the data (Hair et al., 2010). The variables with a factor loading coefficient less than 0.5 will continue to be eliminated in this step. The coefficient extraction method used is the Principal Component extraction method with Varimax rotation, the rotation stops when the extracting elements have an Eigenvalue greater than or equal to 1 (Hair et al., 2010).

The scale is accepted when the total variance extracted is equal to or greater than $50 \%$

After removing the unsuitable variables, the author proceeds to check the suitability of the variables; Simultaneously, Cronbach's Alpha's test is re-performed on groups of variables with corrections to confirm the reliability of the scale.

Step 4: Regression analysis and hypothesis testing

The scales assessed to meet the requirements are included in correlation analysis and regression analysis to test hypotheses. According to Cooper \& Schindler (2006), multiple linear regression is often used to test and explain causality theory.

When ensuring the scale's reliability, regression analysis is used to test hypotheses whether or not the factors affect the expected tuition fees. Moreover, to ensure that the regression model is appropriate, we will test the hypotheses: There is no multi-collinearity phenomenon through the VIF magnification coefficient of variance (Henseler et al., 2009); Constant residual variance (Scatterplot); Remains have a standard distribution (Histogram and P-P plot histogram); There is no correlation between residues (Durbin-Watson test).

Step 5: Test the differences between groups of factors.

Use the Analysis of Variance (ANOVA) method to test the differences in mean values of some factor groups according to qualitative variables.

Part 1:

Levene test: used to test for equality of variance between groups.

HO: "Equal Variance"

Sig <= 0.05: reject hypothesis 
Sig > 0.05: accept hypothesis -> eligible for further Anova

Part 2:

ANOVA test

H0: "Equal average"

$\mathrm{Sig}<=0.05$ : rejects $\mathrm{H} 0$-> eligible to confirm a difference between groups for the dependent variable Sig> 0.05: accept $\mathrm{HO}$-> ineligible to confirm the difference between groups for the dependent variable In this study, the author has an in-depth Post-Hoc analysis to find the differences between groups of observations by LSD tests.

\section{RESULTS AND DISCUSSION}

\subsection{Characteristics of the survey sample}

\section{Characteristics of students}

From all 250 responses from all six public universities mentioned above, according to statistics, the sex ratios of males and females are respectively $41.2 \%$ (103) and 58.8\% (147). Among them are the number of votes for Pedagogy (15), Medicine (58), Economics (116), Law (17), Social science and humanities (35), Construction (9).

\section{Characteristics of households}

TABLE 2. STATISTICS OF RESIDENCE

\begin{tabular}{|c|c|c|}
\hline Residence & Amount & Proportion \\
\hline Mountainous ethnic group (Area 1) & 47 & 18.8 \\
\hline Town or City (Area 2) & 71 & 28.4 \\
\hline Vicinity (Area 2 rural) & 90 & 36.0 \\
\hline Urban districts (Area 3) & 42 & 16.8 \\
\hline Total & 250 & 100 \\
\hline
\end{tabular}

Source: Author's survey data and processing

From table 2, it can be seen that most of the students participating in the survey were from Area 2 and Area 2 rural (27.4\% and 36\%, respectively). The rest are from Area $1(18.8 \%)$ and Area $3(16.8 \%)$. Thus, up to $83.2 \%$ of students come from low and middle-income areas, which will affect the ability to pay for and suitability of current tuition fees.

TABLE 3. STATISTICS OF THE GUARDIAN INCOME

\begin{tabular}{|c|c|c|}
\hline The total guardian income & Amount & Proportion \\
\hline$<500$ USD & 122 & 48,8 \\
\hline $500-1000$ USD & 80 & 32 \\
\hline
\end{tabular}


Nguyen, $\mathrm{T}$.

FACTORS AFFECTING THE TUITION FEE POLICY OF PUBLIC HIGHER EDUCATION

\begin{tabular}{|c|c|c|}
\hline $1000-1500$ USD & 33 & 13,2 \\
\hline $1500-2000$ USD & 11 & 4,4 \\
\hline$>2000$ US & 4 & 1.6 \\
\hline Total & 250 & 100 \\
\hline
\end{tabular}

Source: Author's survey data and processing

According to the Table 3, most of the households' income is below 1000 USD per month. Specifically, in descending order, we have Households with incomes below 500 USD (122 responses - 48.8\%), followed by households with income between 500-1000 USD per month (80 respondents - 32\%) and households with income between 1000-1500 USD per month (33 respondents - 13.2\%). Only $6 \%$ of the households have income above 1500 USD a month.

\section{Characteristics of tuition fee}

TABLE 4. STATISTICS OF THE GOVERNMENT SUPPORT ASSESSMENT

\begin{tabular}{|c|c|c|c|c|}
\hline & Frequency & Percent & Valid Percent & $\begin{array}{c}\text { Cumulative } \\
\text { Percent }\end{array}$ \\
\hline Too high & 13 & 5.2 & 5.2 & 5.2 \\
\hline High & 47 & 18.8 & 18.8 & 24.0 \\
\hline Normal & 133 & 53.2 & 53.2 & 77.2 \\
\hline Low & 46 & 18.4 & 18.4 & 95.6 \\
\hline Too low & 11 & 4.4 & 4.4 & 100.0 \\
\hline Total & 250 & 100.0 & 100.0 & \\
\hline
\end{tabular}

Source: Author's survey data and processing

As stated in the introduction, the state has always provided financial support to public universities; however, there are too many management departments on a limited budget so according to students' assessment in the table 4 above, the level of support is relatively Normal with $53.2 \% .18 .8 \%$ rated it as High, while $18.4 \%$ rated it as Low. $5.2 \%$ rated it as Too High, and $11 \%$ rated it as Too Low. This assessment depends on residence characteristics and each individual's family income.

TABLE 5. STATISTICS OF THE TUITION FEES ASSESSMENT

\begin{tabular}{|c|c|c|c|c|}
\hline & Frequency & Percent & $\begin{array}{c}\text { Valid } \\
\text { Percent }\end{array}$ & $\begin{array}{c}\text { Cumulative } \\
\text { Percent }\end{array}$ \\
\hline Very suitable & 25 & 10.0 & 10.0 & 10.0 \\
\hline Suitable & 90 & 36.0 & 36.0 & 46.0 \\
\hline Normal & 94 & 37.6 & 37.6 & 83.6 \\
\hline Not suitable & 37 & 14.8 & 14.8 & 98.4 \\
\hline Nonsense & 4 & 1.6 & 1.6 & 100.0 \\
\hline Total & 250 & 100.0 & 100.0 & \\
\hline
\end{tabular}

Source: Author's survey data and processing 
Regarding specific values of the university cost, when considering the subjective assessment, the results are as follows: $66.4 \%$ of the students rated the tuition fee they are paying as suitable (166 students). The number of votes for "Normal" is the second-highest number with 90 students, accounting for $36.0 \%$. The rate of "not suitable" response is $14.8 \%$, equivalent to 38 students, while the rate of "very suitable" response is 25 students, accounting for $10 \%$. Moreover, the numbers of students with "unreasonable" and "inappropriate" response are very small, with $2.8 \%$ and $5.6 \%$ respectively. This result shows that most students enrolled in public higher education institutions can afford the current tuition fees. From that, we can classify students, classify appropriate programs, and apply appropriate credit policies for each different group of students.

TABLE 6. STATISTIC OF THE TUITION FEES

\begin{tabular}{|c|c|c|c|c|}
\hline & Frequency & Percent & $\begin{array}{c}\text { Valid } \\
\text { Percent }\end{array}$ & $\begin{array}{c}\text { Cumulative } \\
\text { Percent }\end{array}$ \\
\hline 165 USD/term & 62 & 24.8 & 24.8 & 24.8 \\
\hline 165-250 USD/term & 92 & 36.8 & 36.8 & 61.6 \\
\hline $250-380$ USD/term & 48 & 19.2 & 19.2 & 80.8 \\
\hline $380-450$ USD/term & 28 & 11.2 & 11.2 & 92.0 \\
\hline $450-1000$ USD/term & 18 & 7.2 & 7.2 & 99.2 \\
\hline$>1000$ USD/term & 2 & .8 & .8 & 100.0 \\
\hline Total & 250 & 100.0 & 100.0 & \\
\hline
\end{tabular}

Source: Author's survey data and processing

According to calculations from the survey results, the desired tuition fee is 165-250 USD per semester (330-500 USD per year). There are $24.8 \%$ of students who expect a tuition fee of 165 USD per semester. Regarding the tuition fee between $250-380$ USD, the number is $19.2 \%$ of the students. $28 \%$ would pay a tuition fee from 380 to 450 USD. $7.2 \%$ expect $450-1000$ USD, and only $0.8 \%$ want to pay more than 1000 USD. This expected tuition fee partly matches the income of the guardian and the student's expectation of tuition fees correlating with quality of training. Besides, students themselves can share the costs with families and the school.

\subsection{Analysis of factors affecting public university tuition policy}

\subsubsection{Verify the reliability of the scales with Cronbach Alpha coefficients}

Research on tuition policy factors using the 5-level Likert scale with six hypothetical factors is coded in the following order: Course structure $(\mathrm{Cs})$, Lecturers $(\mathrm{L})$, Curriculum contents $(\mathrm{Cc})$, Teaching methods $(\mathrm{Tm})$, Facilities $(\mathrm{F})$, and Curriculums $(\mathrm{Cr})$. To improve the scale's reliability and eliminate the factors and variables with low confidence levels, the author used Cronbach Alpha coefficients. Accordingly, the calculation of the correlation coefficient between variables - total will help to eliminate any observed 
Nguyen, $\mathrm{T}$.

FACTORS AFFECTING THE TUITION FEE POLICY OF PUBLIC HIGHER EDUCATION

variables that do not contribute much to the description of the measured concept to eliminate the dump variables before factor analysis. The excluded variables are observed variables with the variable-total correlation coefficient of less than 0.3 ; the Criteria select the scale when the alpha reliability is larger than 0.6 (Nunnally \& Bernstein, 1994). The data shows that Cronbach's alpha coefficients of 6 groups all reached over 0.6 . With this result, the scale and the dataset are reliable to conduct exploratory factor analysis.

TABLE 7. CRONBACH ALPHA RELIABILITY COEFFICIENT

\begin{tabular}{|c|c|c|}
\hline Factors & $\begin{array}{c}\text { The Cronbach's Alpha } \\
\text { coefficient }\end{array}$ & N of Items \\
\hline CS & .867 & 3 \\
\hline L & .887 & 6 \\
\hline CC & .824 & 4 \\
\hline TM & .872 & 5 \\
\hline F & .827 & 4 \\
\hline CR & .905 & 12 \\
\hline
\end{tabular}

Source: Author's survey data and processing

\subsubsection{Explore factor analysis (EFA)}

The KMO and Bartlett test results showed that the KMO value reached 0.812 satisfactorily $(0.5<\mathrm{KMO}$ $<1)$, showing that the data was suitable for exploratory factor analysis. The Bartlett test results in Sig value. $=0.000<0.05$ indicates that the factors are linearly correlated in the whole.

TABLE 8. KMO AND BARTLETT TESTING

\begin{tabular}{|c|c|c|}
\hline \multicolumn{2}{|c|}{ Kaiser-Meyer-Olkin Measure of Sampling Adequacy. } & .890 \\
\hline \multirow{3}{*}{ Bartlett's Test of Sphericity } & Approx. Chi-Square & 5561.841 \\
\cline { 2 - 3 } & $\mathrm{df}$ & 561 \\
\cline { 2 - 3 } & Sig. & .000 \\
\hline
\end{tabular}

Source: Author's survey data and processing

TABLE 9. FACTORS ANALYSIS ACCORDING TO PRINCIPAL COMPONENTS

\begin{tabular}{|c|c|c|c|c|c|c|c|c|c|}
\hline \multirow{2}{*}{ Component } & \multicolumn{3}{|c|}{ Initial Eigenvalues } & \multicolumn{3}{c|}{$\begin{array}{c}\text { Extraction Sums of Squared } \\
\text { Loadings }\end{array}$} & \multicolumn{3}{|c|}{$\begin{array}{c}\text { Rotation Sums of Squared } \\
\text { Loadings }\end{array}$} \\
\cline { 2 - 9 } & Total & $\begin{array}{c}\% \text { of } \\
\text { Variance }\end{array}$ & $\begin{array}{c}\text { Cumulative } \\
\%\end{array}$ & Total & $\begin{array}{c}\% \text { of } \\
\text { Variance }\end{array}$ & $\begin{array}{c}\text { Cumulative } \\
\%\end{array}$ & Total & $\begin{array}{c}\% \text { of } \\
\text { Variance }\end{array}$ & $\begin{array}{c}\text { Cumulative } \\
\%\end{array}$ \\
\hline 1 & 12.286 & 36.136 & 36.136 & 12.286 & 36.136 & 36.136 & 4.049 & 11.910 & 11.910 \\
2 & 2.488 & 7.318 & 43.454 & 2.488 & 7.318 & 43.454 & 4.005 & 11.780 & 23.690 \\
3 & 2.112 & 6.213 & 49.667 & 2.112 & 6.213 & 49.667 & 3.681 & 10.827 & 34.517
\end{tabular}


Nguyen, $\mathrm{T}$.

FACTORS AFFECTING THE TUITION FEE POLICY OF PUBLIC HIGHER EDUCATION

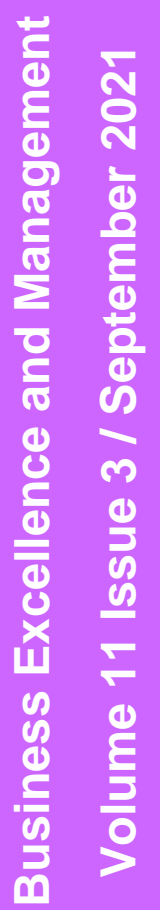

\begin{tabular}{|c|c|c|c|c|c|c|c|c|c|}
\hline 4 & 1.863 & 5.481 & 55.147 & 1.863 & 5.481 & 55.147 & 3.520 & 10.352 & 44.869 \\
\hline 5 & 1.712 & 5.036 & 60.183 & 1.712 & 5.036 & 60.183 & 2.926 & 8.606 & 53.475 \\
\hline 6 & 1.528 & 4.495 & 64.678 & 1.528 & 4.495 & 64.678 & 2.694 & 7.924 & 61.399 \\
\hline 7 & 1.291 & 3.796 & 68.474 & 1.291 & 3.796 & 68.474 & 2.405 & 7.075 & 68.474 \\
\hline 8 & .814 & 2.394 & 70.868 & & & & & & \\
\hline 9 & .751 & 2.210 & 73.078 & & & & & & \\
\hline 10 & .723 & 2.126 & 75.203 & & & & & & \\
\hline 11 & .709 & 2.086 & 77.289 & & & & & & \\
\hline 12 & .673 & 1.980 & 79.269 & & & & & & \\
\hline 13 & .604 & 1.776 & 81.045 & & & & & & \\
\hline 14 & .549 & 1.614 & 82.659 & & & & & & \\
\hline 15 & .532 & 1.565 & 84.224 & & & & & & \\
\hline 16 & .516 & 1.519 & 85.743 & & & & & & \\
\hline 17 & .467 & 1.373 & 87.116 & & & & & & \\
\hline 18 & .442 & 1.301 & 88.416 & & & & & & \\
\hline 19 & .410 & 1.207 & 89.623 & & & & & & \\
\hline 20 & .380 & 1.119 & 90.742 & & & & & & \\
\hline 21 & .346 & 1.017 & 91.758 & & & & & & \\
\hline 22 & .333 & .978 & 92.736 & & & & & & \\
\hline 23 & .325 & .957 & 93.694 & & & & & & \\
\hline 24 & .312 & .918 & 94.612 & & & & & & \\
\hline 25 & .288 & .846 & 95.458 & & & & & & \\
\hline 26 & .274 & .805 & 96.263 & & & & & & \\
\hline 27 & .236 & .693 & 96.956 & & & & & & \\
\hline 28 & .220 & .646 & 97.602 & & & & & & \\
\hline 29 & .193 & .566 & 98.168 & & & & & & \\
\hline 30 & .154 & .454 & 98.622 & & & & & & \\
\hline 31 & .145 & .428 & 99.050 & & & & & & \\
\hline 32 & .125 & .367 & 99.417 & & & & & & \\
\hline 33 & .104 & .307 & 99.724 & & & & & & \\
\hline 34 & .094 & .276 & 100.000 & & & & & & \\
\hline
\end{tabular}

Source: Author's survey data and processing

The factor analysis is performed according to Principal components with Varimax rotation. 
Nguyen, $\mathrm{T}$.

FACTORS AFFECTING THE TUITION FEE POLICY OF PUBLIC HIGHER EDUCATION

The results showed that the initial 34 observed variables were grouped into seven groups.

Value of total variance extracted $=68.474 \%>50 \%$ : satisfactory; then it can be said that these seven factors account for $68.474 \%$ of the data variation.

The Eigenvalues coefficient values of all factors are high (>1); factor 7 has the lowest Eigenvalues of $1.291>1$.

TABLE 10. FACTOR MATRIX AFTER ROTATION

\begin{tabular}{|c|c|c|c|c|c|c|c|}
\hline & \multicolumn{7}{|c|}{ Component } \\
\hline & 1 & 2 & 3 & 4 & 5 & 6 & 7 \\
\hline $\begin{array}{c}\text { L4 } \\
\text { L5 } \\
\text { L2 } \\
\text { L1 } \\
\text { L3 } \\
\text { L6 } \\
\text { CR11 } \\
\text { CR3 } \\
\text { CR1 } \\
\text { CR5 } \\
\text { CR2 } \\
\text { CR4 } \\
\text { CR12 } \\
\text { CR6 } \\
\text { CR7 } \\
\text { CR9 } \\
\text { CR10 } \\
\text { CR8 } \\
\text { TM2 } \\
\text { TM1 } \\
\text { TM3 } \\
\text { TM5 } \\
\text { TM4 } \\
\text { F2 } \\
\text { F4 } \\
\text { F1 } \\
\text { F3 } \\
\text { CC3 } \\
\text { CC2 } \\
\text { CC4 } \\
\text { CC1 } \\
\text { CS2 } \\
\text { CS1 } \\
\text { CS3 }\end{array}$ & $\begin{array}{l}.803 \\
.781 \\
.752 \\
.720 \\
.689 \\
.676\end{array}$ & $\begin{array}{l}.826 \\
.802 \\
.796 \\
.680 \\
.665 \\
.607\end{array}$ & $\begin{array}{l}.770 \\
.750 \\
.719 \\
.715 \\
.635 \\
.587\end{array}$ & $\begin{array}{l}.760 \\
.750 \\
.742 \\
.718 \\
.630\end{array}$ & $\begin{array}{l}.787 \\
.786 \\
.660 \\
.656\end{array}$ & $\begin{array}{l}.806 \\
.776 \\
.741 \\
.587\end{array}$ & $\begin{array}{l}.795 \\
.788 \\
.761\end{array}$ \\
\hline
\end{tabular}

Source: Author's survey data and processing 
Based on the sample matrix, seven new factors were formed and reassigned the variables as follows: (1) Lecturers (L), (2) Curriculums (Cr), (3) Student skills (Ss), (4) Teaching methods (Tm), (5) Facilities (F), (6) Curriculum contents (Cc), (7) Course structure (Cs).

TABLE 11. CRONBACH ALPHA RELIABILITY COEFFICIENT

\begin{tabular}{|c|c|c|}
\hline & $\begin{array}{c}\text { The Cronbach's Alpha } \\
\text { coefficient }\end{array}$ & N of Items \\
\hline CR & .890 & 6 \\
\hline SS & .889 & 6 \\
\hline
\end{tabular}

Source: Author's survey data and processing

The new scales are also tested for reliability of the Cronbach Alpha scale. Each new factor group has a Cronbach Alpha coefficient greater than 0.6 , proving that the intrinsic relationship of the elements in each new group is quite close (Nunnally, J.C., \& Bernstein, I.H, 1994).

\subsection{Regression and correlation analysis}

TABLE 12. EVALUATE THE SUITABILITY OF THE MODEL

\begin{tabular}{|c|c|c|c|c|c|}
\hline Model & $\mathrm{R}$ & $\mathrm{R}$ Square & Adjusted R Square & $\begin{array}{c}\text { Std. Error of the } \\
\text { Estimate }\end{array}$ & Durbin-Watson \\
\hline 1 & $.670^{\mathrm{a}}$ & .449 & .433 & .61599 & 1.698 \\
\hline
\end{tabular}

Source: Author's survey data and processing

Based on the results from the table above, the model's seven independent variables affect $43.30 \%$ on the change of the dependent variable, and the rest $56.70 \%$ is due to the non-model variables and random error.

The results show that the Durbin-Watson coefficient is 1,698 , satisfying the condition $(1<$ Durbin Watson $<3$ ), inferring the correlation between the residues is very small, and the model has no autocorrelation phenomenon. Thus, from the tests, it can be seen that the assumptions of the linear regression analysis are not violated. The results of regression analysis are reliable.

TABLE 13. CORRELATION ANALYSIS

\begin{tabular}{|cc|c|c|c|c|c|}
\hline \multicolumn{1}{|c|}{ Model } & Sum of Squares & $\mathrm{df}$ & Mean Square & $\mathrm{F}$ & Sig. \\
\hline \multirow{4}{*}{1} & Regression & 74.798 & 7 & 10.685 & 28.161 & $.000^{\mathrm{b}}$ \\
& Residual & 91.826 & 242 & .379 & & \\
& Total & 166.624 & 249 & & & \\
\hline
\end{tabular}

Source: Author's survey data and processing 
Correlation analysis results show the correlation relationship between the expected tuition variable (the dependent variable) and the influencing factors (independent variable). Sig value. $<0.05$ shows that the independent variables are correlated with the dependent variable, which is appropriate for conducting regression analysis. Also, in this case, the relationships are in the same direction.

Conduct a regression analysis to test whether there are any effects of these factors on the expected tuition rate. At the same time, determine each factor's impact (independent variable) on the expected tuition fee (dependent variable).

We have the following regression model:

\section{$T F=\beta 1 \times L+\beta 2 \times C R+\beta 3 \times S S+\beta 4 \times T M+\beta 5 \times F+\beta 6 \times C C+\beta 7 \times C S$}

In which TF is the expected tuition fee (dependent variable); $\beta 1$ to $\beta 7$ are regression coefficients that indicate the influence of the factors; Lecturers (L), Curriculums (Cr), Student skills (Ss), Teaching methods $(\mathrm{Tm})$, Facilities (F), Curriculum contents $(\mathrm{Cc})$, Course structure (Cs)

The standardized estimated regression model are as follows:

TABLE 14. RESULTS OF MULTIVARIATE REGRESSION ANALYSIS

\begin{tabular}{|c|c|c|c|c|c|c|c|c|c|}
\hline \multirow{2}{*}{ Model } & \multicolumn{2}{|c|}{$\begin{array}{l}\text { Unstandardized } \\
\text { Coefficients }\end{array}$} & \multirow{2}{*}{\begin{tabular}{|c|c|}
$\begin{array}{c}\text { Standardized } \\
\text { Coefficients }\end{array}$ \\
Beta
\end{tabular}} & \multirow{2}{*}{$t$} & \multirow{2}{*}{ Sig. } & \multicolumn{2}{|c|}{$\begin{array}{l}95.0 \% \text { Confidence } \\
\text { Interval for B }\end{array}$} & \multicolumn{2}{|c|}{$\begin{array}{l}\text { Collinearity } \\
\text { Statistics }\end{array}$} \\
\hline & B & Std. Error & & & & $\begin{array}{l}\text { Lower } \\
\text { Bound }\end{array}$ & $\begin{array}{l}\text { Upper } \\
\text { Bound }\end{array}$ & Tolerance & VIF \\
\hline (Constant) & 3.752 & .039 & & 96.307 & .000 & 3.675 & 3.829 & & \\
\hline$L$ & .137 & .039 & .167 & 3.504 & .001 & .060 & .214 & 1.000 & 1.000 \\
\hline CR & .248 & .039 & .303 & 6.354 & .000 & .171 & .325 & 1.000 & 1.000 \\
\hline SS & .271 & .039 & .331 & 6.945 & .000 & .194 & .348 & 1.000 & 1.000 \\
\hline TM & .217 & .039 & .265 & 5.548 & .000 & .140 & .293 & 1.000 & 1.000 \\
\hline$F$ & .191 & .039 & .234 & 4.903 & .000 & .115 & .268 & 1.000 & 1.000 \\
\hline CC & .160 & .039 & .196 & 4.097 & .000 & .083 & .237 & 1.000 & 1.000 \\
\hline CS & .194 & .039 & .237 & 4.963 & .000 & .117 & .271 & 1.000 & 1.000 \\
\hline
\end{tabular}

Source: Author's survey data and processing

Sig regression coefficients of the independent variables are less than 0.05 , so these independent variables are meant to explain the dependent variable, and no variable is removed. VIF coefficients are all less than 2, so no multicollinearity occurs.

Thus, the normalized regression equation would be:

$T F=0.167 \times L+0.303 \times C R+0.331 \times S S+0.265 \times T M+0.234 \times F+0.196 \times C C+0.237 \times C S$ 
Based on the regression results of the Table 14 above, it can be seen that because the coefficient $\square=$ 0.331 is the largest of all the factors analyzed, the SS has the most influence on the expected tuition fees of students, followed by CR (0.303). The factors of TM, CS, F also have a big influence with a coefficient $\square$ of $0.265 ; 0.237$, and 0.234 , respectively. Factor $L$ and $C C$ have the least influence on the expected tuition fee with a coefficient $\square$ of 0.167 and 0.196 , respectively.

\section{Histogram}

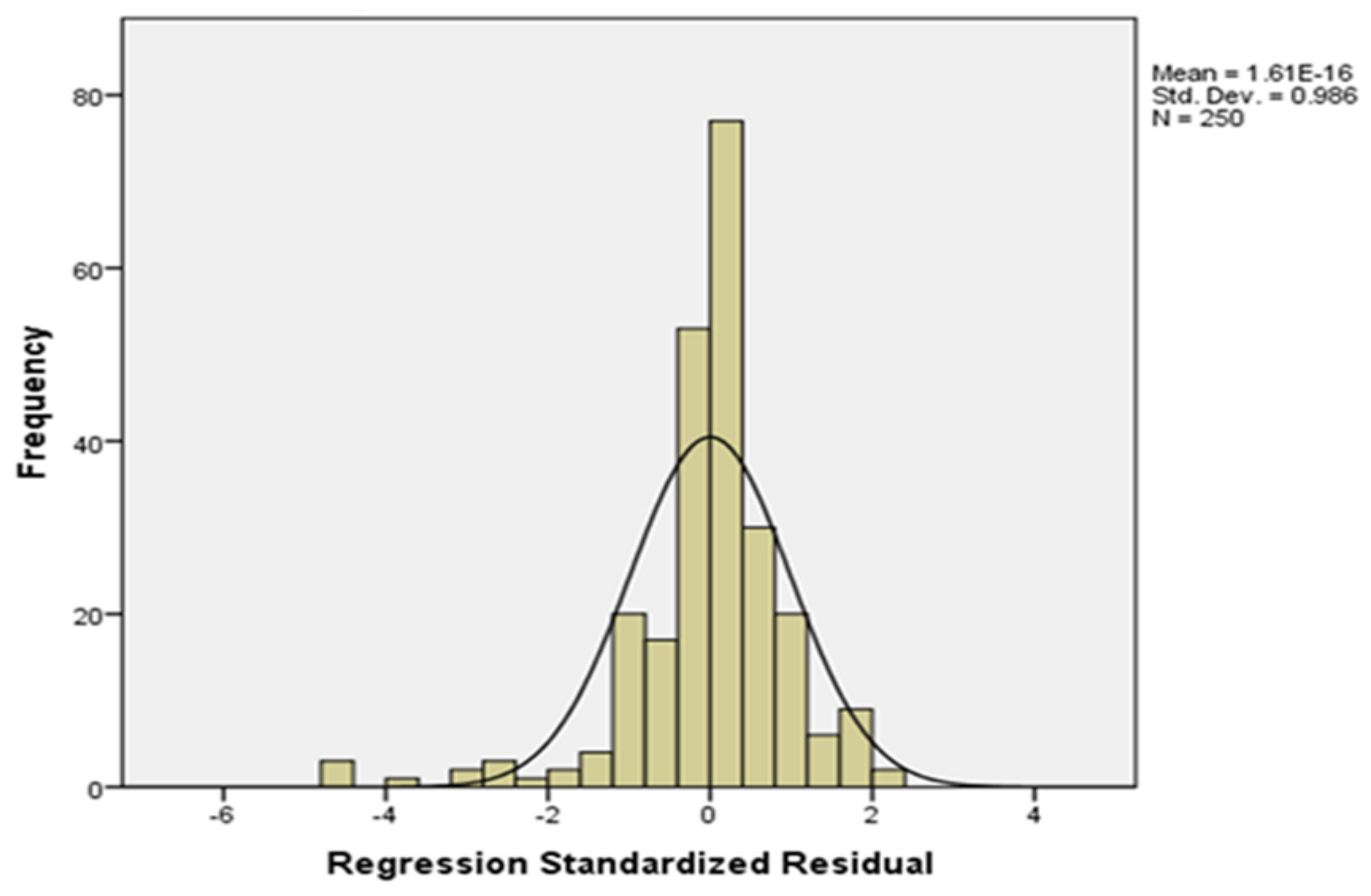

GRAPH 1. THE NORMAL DISTRIBUTION OF THE REMAINDER

Source: Author's survey data and processing

From the graph, we can see, a normal distribution curve is superimposed on the histogram. This curve has a bell shape, which is consistent with the standard distribution graph. The Mean value is close to 0 , and the standard deviation is 0.986 close to 1 , so it can be said that the residual distribution is approximately standard. Therefore, it can be concluded that: the standard distribution hypothesis of the residual is not violated. 
Nguyen, $\mathrm{T}$.

FACTORS AFFECTING THE TUITION FEE POLICY OF PUBLIC HIGHER EDUCATION

4.4. Examine the differences in student's perceptions related to the factors that affect student's expected tuition fees.

TABLE 15. INDEPENDENT SAMPLES TEST

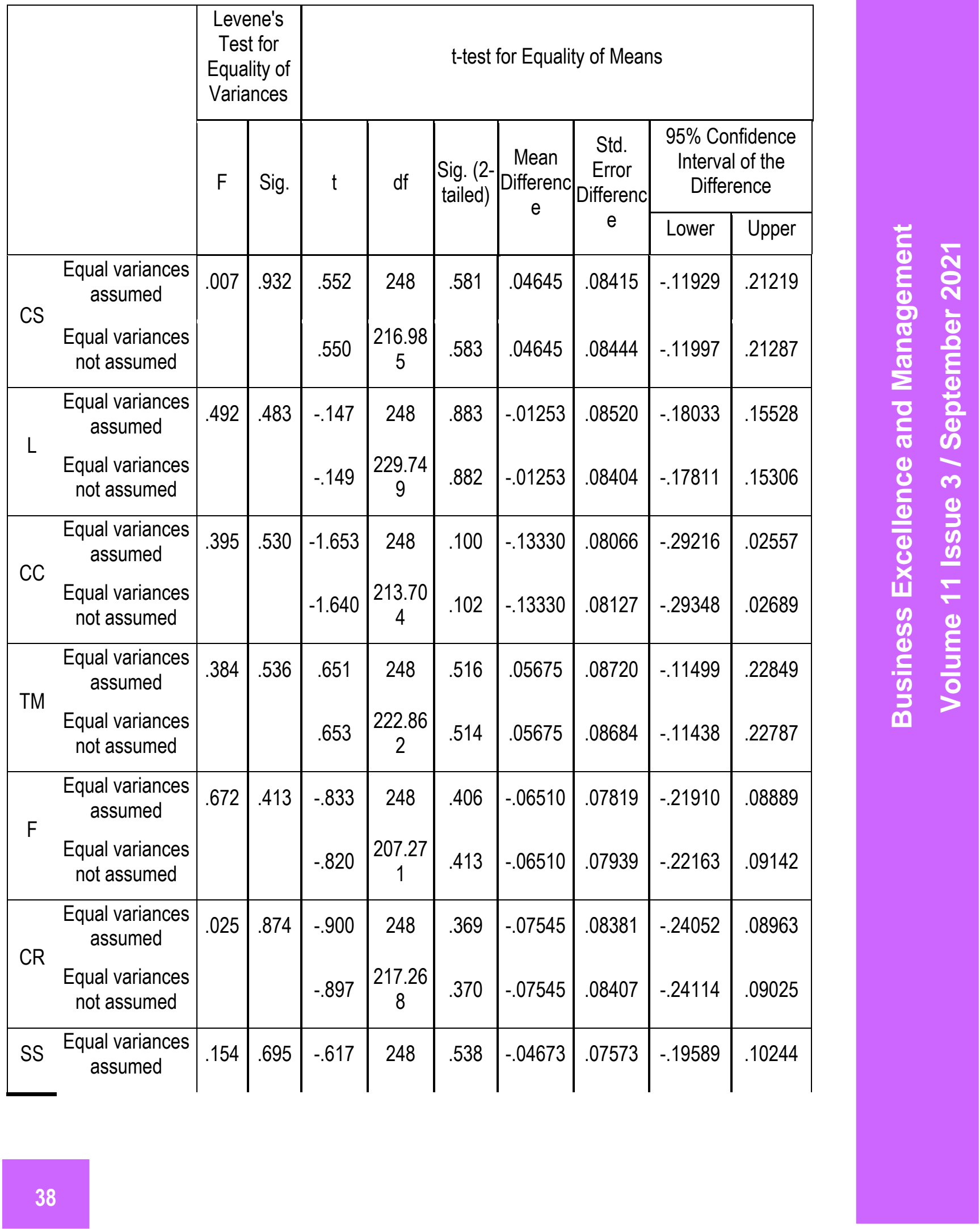


Equal variances not assumed $-.615$ $\mid \begin{gathered}216.51 \\ 2\end{gathered}$ \begin{tabular}{l|l}
.540 & -.04673 \\
\hline
\end{tabular} \begin{tabular}{|l|l|l|}
.07604 & -.19660 & .10314 \\
\hline
\end{tabular}

Source: Author's survey data and processing

TABLE 16. DIFFERENCES IN PERCEPTION BETWEEN DIFFERENT GROUPS OF LEARNERS

\begin{tabular}{|c|c|c|c|c|}
\hline \multirow{2}{*}{$\begin{array}{c}\text { Groups of } \\
\text { factors }\end{array}$} & \multirow{2}{*}{ Mean } & \multicolumn{3}{|c|}{ Independent variables } \\
\cline { 3 - 5 } & & Universities & Residence & $\begin{array}{c}\text { Total guardian } \\
\text { income }\end{array}$ \\
\hline CS & 3.8400 & $*$ & $n s$ & $* *$ \\
\hline L & 3.8973 & $*$ & $n s$ & $n s$ \\
\hline CC & 3.9910 & ns & ns & ${ }^{* *}$ \\
\hline TM & 3.9744 & $*$ & $n s$ & $*$ \\
\hline F & 4.0310 & ns & ns & $*$ \\
\hline CR & 4.0120 & ns & ns & $* *$ \\
\hline SS & 3.9433 & $*$ & $n s$ & $* *$ \\
\hline
\end{tabular}

Source: Author's survey data and processing

Note

ns: (Sig. $>0,1)$ there is no statistically significant difference.

*: $(0.05<$ Sig. $<=0,1)$ there is a difference that is statistically significant with a low level of significance.

$* *:(0.01<$ Sig. $<=0,05)$ there is a difference that is statistically significant with a medium level of significance.

***: (Sig. $<=0,01)$ there is a difference that is statistically significant with a high level of significance.

The ANOVA analysis results show no statistically significant difference between students having different residence places regarding statements about groups of factors: Lecturers, Curriculums, Student skills, Teaching methods, Facilities, Curriculums content, Course structure.

The results in the table 16 showed that, among students of different sexes, there was no statistically significant difference regarding statements about groups of factors: Lecturers, Curriculums, Student skills, Teaching methods, Facilities, Course structure, Curriculum Contents factor.

There is no statistically significant difference for students in different training institutions for the curriculum, facilities, and curriculum factors. However, there is a statistically significant difference in the groups of course structure, faculty, and teaching methods. In medical and civil engineering universities, it is necessary to pay attention to the course structure. The training time of these two disciplines is longer than that of other groups, and the internship with these two schools is relatively late (medical students go to 
clinical training in year 3, civil engineer students go on field trips in year 4). Thus, the curriculum framework is spread out and heavy in theory. Teaching methods lack practicality, leading to inadequate practical skills. Many students also assess that lecturers have not updated new knowledge, and old-fashioned thinking leads to unfair assessment and not promotes students' capacity. Therefore, it is necessary to adjust these factor groups: course structure, lecturers, teaching methods.

The difference in household income among learners was not statistically significant for the lecturers factors and the difference was statistically significant for factors of course structure, curriculums contents, curriculums, and student skills; For factors of teaching methods and household income, the difference has a low statistical significance. This result proves that household income will predominantly determine whether the training period and program framework are suitable for household income or not, and whether the teaching method is appropriate for the household's investment cost.

\section{CONCLUSION}

Derived from the survey and test results of the factors affecting students' expected tuition fees, there is a positive impact of these factors. Therefore, the author proposes some implications from a personal point of view for managers to promote the completion of tuition policies at Vietnamese public universities as follows:

First, public universities should invest in building program activities to train and improve skills for students. It would not be enough if the public university were only equipping students with some career skills because employers' skill requirements can change over time as technology and global labor markets change rapidly. This can be seen easily as the World Economic Forum's top 10 career skills adjusted every five years. Meanwhile, having an open mind, a willingness to learn, a professional attitude, and being responsible for themselves and society, workers will be able to quickly adapt to any circumstances of the changing labor market. This content demands more attention because it is the factor that has the strongest impact on the expected tuition fees of students.

Second, public universities need to focus on programs that meet the basic career skills students need to master. The current curriculum in Vietnam is relatively heavy in theory and lacks practical skills. Especially in the context of globalization, the labor market needs students that are highly capable of foreign languages and computer skills.

Third, public universities need to pay attention to perfecting and renovating teaching methods. Instead of transmitting knowledge mechanically, it is necessary to change teaching methods based on practice, modern teaching methods, and application of information and communication technology. Moreover, 
teaching methods must focus on the student. Besides, teaching methods must promote the activeness, initiative, creativity, and application of students' knowledge and skills.

Fourth, public universities need to build and disseminate the course structure to students as soon as they enter the school. Building the suitable structure will help students be more active in arranging and choosing the right subjects for students in the current context of credit learning instead of following distribution by the school as before.

Fifth, public universities should increase investment in modern facilities to meet students' needs of accommodation, practice, experiment, etc, helping them adapt to the development of the 4.0 Technology Revolution, in line with new teaching methods, thus contributing to improving the quality of training.

Sixth, public universities should focus on training and promoting the quality of the faculty, tending to several basic stages: Recruitment, teacher evaluation, retraining, and appropriate remuneration.

Seventh, public universities need to pay attention to refining and renewing program content. It is necessary to tap into and develop more training majors as well as training forms to meet new trends. In addition to the basic knowledge, there should be additional seminars to support the main subjects of the major. The content of the program must be discussed and changed to suit the changing world trends.

\section{REFERENCES}

Abdullah, F. (2005). HEdPERF versus SERVPERF: The quest for ideal measuring instrument of service quality in higher education sector. Quality Assurance in Education, 305-328.

Arambewela, R., \& J, H. (2006). A Comparative Analysis of International Education SatisfactionUsing Servqual. Journal of Services Research, 141-163.

Biggs, J. (1993). From Theory to Practice: A Cognitive Systems Approach. Higher Education Research \& Development.

Brian, M. (2010). The price of higher education: how rational is British tuition fee policy? Journal of Higher Education Policy and Management, Vol. 32, 85-95.

Callender, C. (2006). Access to higher education in Britain: The impact of tuition fees and financial assistance. Teixeira, P.N.

Chapman, D. (1981). A model of student college choice. Journal of Higher Education, 490-505.

Chua, C. (2004). Perception of Quality in Higher Education. Proceedings of the Australian Universities Quality Forum.

Cooper, D., \& Schindler, P. (2006). Business Research Methods. McGraw-Hill Irwin.

Dongping, Y. (2006). An analysis of commodification of education. Chinese Education and Society, 5562.

Farahmandian, S., Minavand, H., \& Afshardost, M. (2013). Perceivedservice quality and studentsatisfaction in higher education. Journal of Business and Management, 65-74. 
Fitzpatrick, M., Davey, J., \& Dai, L. (2012). Chinese students' complaining behavior: hearing the silence. Asia Pacific Journal of Marketing and Logistics, 138-754.

Hafiz, B., \& Shaari, J. (2013). Confirmatory factor analysis (CFA) of first order factor measurement modelICT empowerment in Nigeria. International Journal of Business Management and Administration, 8188.

Hair, J., Black, W., Babin, B., \& Anderson, R. (2010). Multivariate Data Analysis: A Global Perspective (7th Edition). Pearson Education.

Heller, D. (1997). Student price response in higher education: An update to Leslie and Brinkman. Journal of Higher Education, 624-659.

Henseler, J., Ringle, C., \& Sinkovics, R. (2009). The use of partial least squares path modeling in international marketing. New Challenges to International Marketing, 277-319.

Huang, W., \& Wu, H. (2008). Market distortion and the tuition pricing mechanism of higher education in China. International Education Studies.

Hung, T. Q. (2016). Vietnam's university tuition policy.

Jungblut, J., \& Vukasovic, M. (2017). Not all markets are created equal: re-conceptualizing market elements in higher education. Higher Education, 855-870.

Kobe University, \& UNESCO Bangkok. (2014). Education finance and administration guidebook.

Leslie, L., \& Brinkman, P. (1987). Student price response in higher education. Journal of Higher Education, 181-204.

Likert, R. (1932). A Technique for the measurement of attitudes. Archives of Psychology.

Merican, F., Zailani, S., \& Fernando, Y. (2009). Development Of MBA Program-Service Quality Measurement Scale. International Review of Business Research Papers, 280-291.

Nunnally, J., \& Bernstein, I. (1994). Psychometric theory. New York.

Parasuraman, A., Zeithaml, V., \& Berry, L. (1988). A Multiple-Item Scale for Measuring Consumer Perceptions of Service Quality. Journal of Retailing, 12-40.

Department for Education and Skills (2003). The future of higher education. Norwich: The Stationery Office.

Teixeira, P., \& Dill, D. (2011). Public Vices, Private Virtues? Assessing the Effects of Marketization in Higher Education. Rotterdam, Boston, Taipei: Sense Publishers.

Thomas, E., \& Galambos, N. (2004). What Satisfies Students? Mining Student-Opinion Data with Regression and Decision Tree Analysis. Research in Higher Education, 251-269. 